\title{
FAKTOR-FAKTOR YANG MEMENGARUHI KEPUTUSAN PEMBELIAN HIJAB MEREK RABBANI PADA CV. RABBANI ASYSA CABANG PADANGSIDIMPUAN
}

\section{Aswadi Lubis, Rodame Monitorir Napitupulu, Rosnita Fitri Siregar}

IAIN Padangsidimpuan

Jalan T. Rizal Nurdin Km. 4,5 Sihitang, Padangsidimpuan

Email : zulaikamatondang83@gmail.com

\begin{abstract}
Abstrak,
Hijab merupakan salah satu kebutuhan pokok sandang kaum muslimah. CV. Rabbani Asysa merupakan salah satu produsen hijab Indonesia dan merupakan merek yang terkenal secara nasional. Pada tahun 2015, hijab merek Rabbani merupakan peraih topbrand award yang menduduki urutan pertama namun pada tahun berikutnya 2016 dan 2017, mengalami penurunan dan berada di posisi kedua. Berdasarkan permasalahan tersebut maka peneliti melakukan penelitian ini, untuk mengetahui faktor-faktor yang memengaruhi keputusan pembelian hijab Rabbani. Tujuan penelitian ini untuk mengetahui pengaruh harga, kualitas dan merek terhadap keputusan pembelian hijab merek Rabbani pada CV. Rabbani Asysa Cabang Padangsidimpuan secara parsial dan simultan. Teori yang digunakan dalam penelitian ini adalah teori tentang harga, kualitas, merek dan teori keputusan pembelian hijab merek Rabbani pada CV. Rabbani Asysa Cabang Padangsidimpuan. Penelitian ini merupakan penelitian kuantitatif dengan teknik pengumpulan data berupa wawancara, kuesioner dan observasi. Populasi pada penelitian ini adalah masyarakat/ konsumen dari hijab merek Rabbani pada CV. Rabbani Asysa Cabang Padangsidimpuan. Pengambilan sampel menggunakan metode accidental sampling dan untuk metode penentuan ukuran sampel menggunakan pendapat Gay dan Airasian dalam Umar (2013). Pengolahan data dilakukan dengan menggunakan bantuan SPSS Versi 23. Analisis data menggunakan uji validitas, reliabilitas, normalitas, linieritas, uji asumsi klasik, uji regresi linier berganda dan uji hipotesis. Hasil penelitian ini menunjukkan bahwa secara parsial harga mempunyai pengaruh yang signifikan terhadap keputusan pembelian hijab merek Rabbani thitung $>$ tabel $(2,185>1,989)$, kualitas mempunyai pengaruh yang signifikan terhadap keputusan pembelian hijab merek Rabbani thitung $>$ tabel $(2,571>1,989)$, dan merek mempunyai pengaruh yang signifikan terhadap keputusan pembelian hijab merek Rabbani thitung $>$ ttabel $(10,953>1,989)$. Secara simultan harga, kualitas dan merek mempunyai pengaruh yang signifikan terhadap keputusan pembelian hijab merek Rabbani pada CV. Rabbani Asysa Cabang Padangsidimpuan yakni thitung $>t_{\text {tabel }}(85,141>2,72)$. Berdasarkan uji koefisien determinasi $\left(\mathrm{R}^{2}\right)$ diketahui bahwa $75 \%$ harga, kualitas dan merek memengaruhi keputusan pembelian hijab merek Rabbani pada CV. Rabbani Asysa Cabang Padangsidimpuan, sedangkan 25\% lagi dipengaruhi oleh variabel yang tidak dibahas dalam penelitian ini.
\end{abstract}

Kata Kunci : Harga, Kualitas, Merek dan Keputusan Pembelian 


\title{
FAKTOR-FAKTOR YANG MEMENGARUHI KEPUTUSAN PEMBELIAN HIJAB MEREK RABBANI PADA CV. RABBANI ASYSA CABANG PADANGSIDIMPUAN
}

\begin{abstract}
,
Hijab is one of the basic needs of Muslim clothing. CV. Rabbani Asysa is one of the Indonesian hijab producers and is a nationally well-known brand. In 2015, the Rabbani brand hijab was the winner of the topbrand award that ranked first but in the following years 2016 and 2017, it declined and was in second place. Based on these problems, the researchers conducted this study, to determine the factors that influence the purchase decision of Rabbani hijab. The purpose of this study was to determine the effect of price, quality and brand on the decision to purchase the Rabbani brand hijab on CV. Rabbani Asysa Branch Padangsidimpuan partially and simultaneously. The theory used in this study is a theory about the price, quality, brand and theory of purchasing decisions of the Rabbani brand on the CV. Rabbani Asysa Branch of Padangsidimpuan. This research is a quantitative research with data collection techniques in the form of interviews, questionnaires and observations. The population in this study is the community / consumers of the Rabbani brand hijab on CV. Rabbani Asysa Branch of Padangsidimpuan. Sampling using accidental sampling method and for the method of determining sample size using the Gay and Airasian opinion in Umar (2013). Data processing is done by using SPSS Version 23. Data analysis uses validity, reliability, normality, linearity, classic assumption test, multiple linear regression test and hypothesis test. The results of this study indicate that partially the price has a significant effect on the purchase decision of Rabbani brand hijab $t$ count $>t$ table (2.185> 1.989), quality has a significant influence on the Rabbani brand hijab purchase decision $t$ count $>t$ table (2.571> 1.989), and the brand has significant effect on the purchase decision of Rabbani brand hijab t count $>t$ table $(10,953>1,989)$. Simultaneously the price, quality and brand have a significant influence on the decision to purchase the Rabbani brand hijab on the CV. Rabbani Asysa Branch Padangsidimpuan namely tcount $>t$ table (85.141> 2.72). Based on the test of the coefficient of determination (R2) it is known that $75 \%$ of the price, quality and brand influence the decision to purchase the Rabbani brand hijab on the CV. Rabbani Asysa Branch Padangsidimpuan, while 25\% again influenced by variables not discussed in this study.
\end{abstract}

Keywords: Price, Quality, Brand and Purchasing Decision

\section{PENDAHULUAN}

CV. Rabbani Asysa merupakan salah satu perusahaan hijab yang memiliki citra merek yang kompetitif. Pada tahun 2015 hijab merek Rabbani merupakan hijab pilihan konsumen yang meraih predikat top. Akan tetapi, pada tahun 2016 posisi hijab merek Rabbani telah di geser oleh hijab merek Zoya. Dan tahun 2017, meskipun hijab merek Rabbani mengalami peningkatan, sayangnya belum mampu untuk merebut posisi pertama yang sudah pernah didudukinya pada tahun 2015. Berikut ini peneliti sajikan tabel mengenai hijab-hijab bermerek pilihan konsumen menurut hasil dari Top brand Award Indonesia : 
Volume 6 Nomor 1 Ed. Januari-Juni 2018 : hal. 38-57

p-ISSN: 2356-4628 e-ISSN : 2579-8650

Tabel I. 1

Topbrand Hijab Bermerek 2015-2017

Sumb

\begin{tabular}{|c|c|c|c|c|c|c|c|c|}
\hline \multirow{2}{*}{\multicolumn{3}{|c|}{$\begin{array}{l}\text { e Tahun } 2015 \\
\text { Kerudung Bermerek }\end{array}$}} & \multicolumn{3}{|c|}{ Tahun 2016} & \multicolumn{3}{|c|}{ Tahun 2017} \\
\hline & & & Kerud & g Be & erek & Kerud & g Ber & erek \\
\hline $\begin{array}{l}\text { Merek } \\
\underline{w} \\
\underline{w}\end{array}$ & $\begin{array}{l}\text { TBI } \\
(\%)\end{array}$ & TOP & Merek & $\begin{array}{l}\text { TBI } \\
(\%)\end{array}$ & TOP & Merek & $\begin{array}{l}\text { TBI } \\
(\%)\end{array}$ & TOP \\
\hline Rebbani & 36.5 & TOP & Zoya & 44.8 & TOP & Zoya & 39.4 & TOP \\
\hline$\underline{Z}_{\underline{\underline{Z}}}^{\text {Zoya }}$ & 28.9 & TOP & Rabbani & 21.3 & TOP & Rabbani & 26.8 & TOP \\
\hline $\begin{array}{l}\text { Eqzatta } \\
p\end{array}$ & 8.4 & & Elzatta & 12.6 & TOP & Elzatta & 13.0 & TOP \\
\hline$\underline{b}$ & & & & & & Azzura & 2.5 & \\
\hline
\end{tabular}

and-award.comdiakses tanggal 09 Januari 2018, 19:28

Tabel tersebut merupakan hasil dari riset yang dilakukan oleh Topbrand award fase kedua dari tahun 2015 hingga tahun 2017. Dari data tersebut, maka peneliti menemukan penurunan pada merek hijab Rabbani sebesar $15,2 \%$, dalam waktu satu tahun, sedangkan Zoya dan Elzatta mengalami peningkatan. Pada tahun berikutnya hijab merek Rabbani memang mengalami peningkatan, akan tetapi belum bisa melampaui hijab merek Zoya, dan persentasi untuk hijab merek Rabbani belum mencapai persentasi awal yang raih oleh hijab merek Rabbani pada tahun 2015.

Berdasarkan uraian tersebut dalam penelitian ini peneliti hendak berfokus pada faktorfaktor yang memengaruhi keputusan pembelian hijab merek Rabbani pada CV.Rabbani Asysa Cabang Padangsidimpuan. Adapun faktor-faktor yang menjadi fokus penelitian peneliti adalah faktor harga, kualitas, dan merek. Sehingga berdasarkan latar belakang di atas maka peneliti tertarik untuk melakukan penelitian dengan judul "FAKTOR-FAKTOR YANG MEMENGARUHI KEPUTUSAN PEMBELIAN HIJAB MEREK RABBANI PADA CV.RABBANI ASYSA CABANG PADANGSIDIMPUAN" 


\section{FAKTOR-FAKTOR YANG MEMENGARUHI KEPUTUSAN \\ PEMBELIAN HIJAB MEREK RABBANI PADA CV. RABBANI ASYSA \\ CABANG PADANGSIDIMPUAN}

\section{TINJAUAN TEORITIK}

\section{Keputusan pembelian}

Berikut ini gambar mengenai model sederhana pengambilan keputusan konsumen (Leon Schiffman dan Lislie Lazar Kanuk, 2007).

Gambar II. 1

Model Sederhana Pengambilan Keputusan

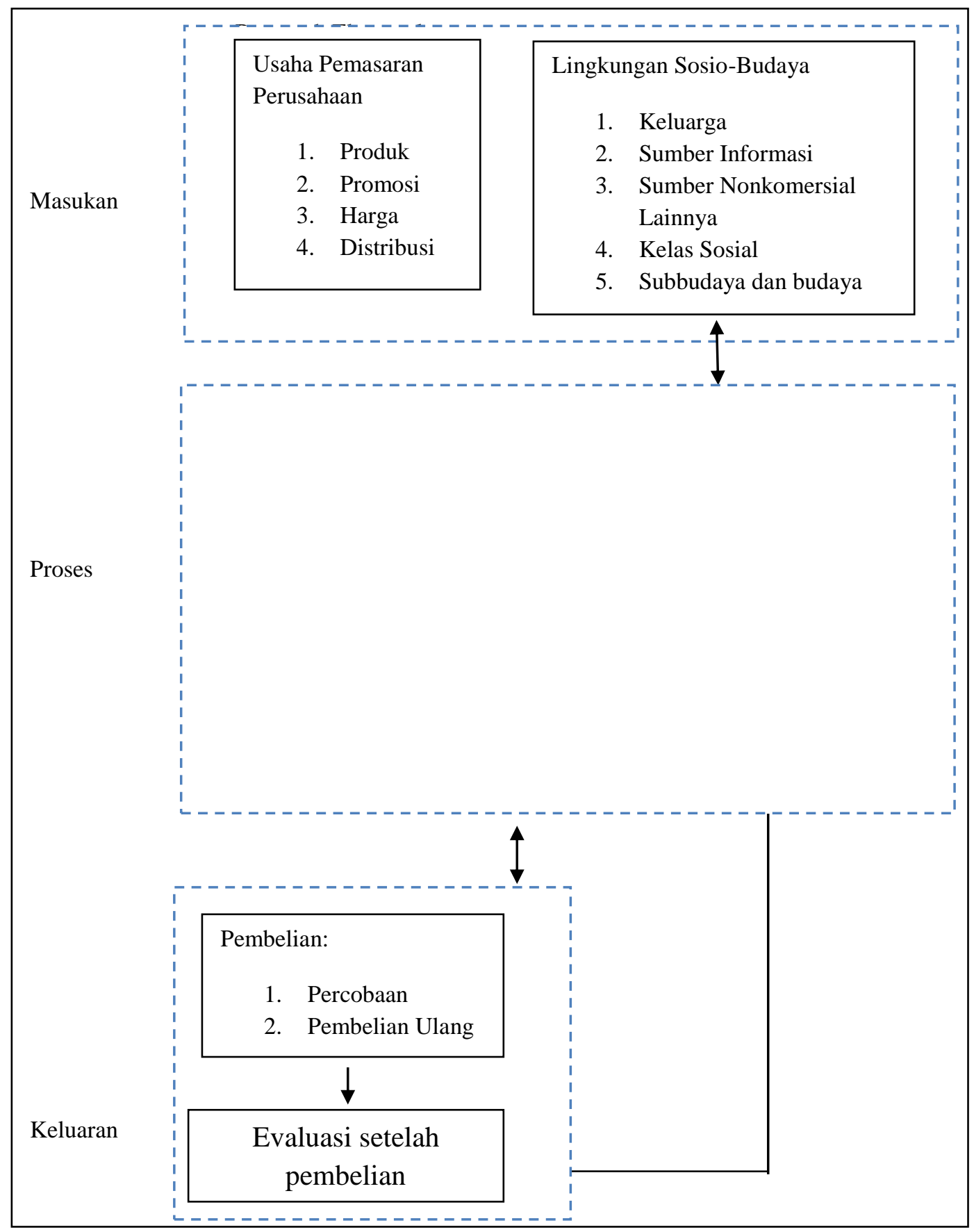




\section{Proses Pengambilan Keputusan Model 5 (Lima) Tahap}

Proses pengambilan keputusan konsumen secara umum akan melalui tahap-tahap berikut ini (Philip Kotler dan Kevin Lane Keller, 2008):

\section{GambarII. 2}

Model Lima Tahap Proses Pembelian Konsumen

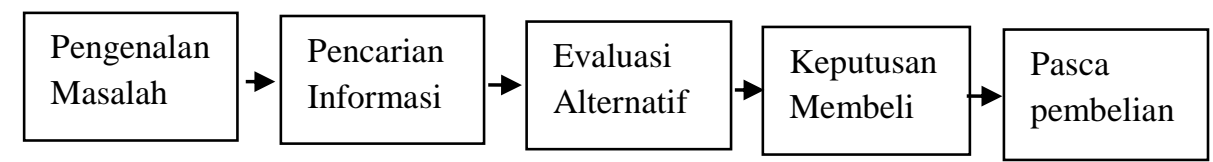

Sumber: Philip Kotler dan Kevin Lane Keller(Manajemen Pemasaran, 2008)

1) Tahap Pengenalan Masalah

Tahap pengenalan masalah dimulai dengan adanya kesadaran konsumen akan kebutuhan yang dibutuhkannya. Hal ini dapat dipicu oleh faktor internal (diri konsumen) dan faktor eksternal (luar diri konsumen).

2) Tahap Pencarian Informasi

Menyadari adanya kebutuhan maka konsumen akan dengan sendirinya mencari pemuas kebutuhannya dan yang mampu menyelesaikan masalahnya. Hal inilah yang terjadi pada tahap pencarian informasi.

3) Tahap Evaluasi Alternatif

Berdasarkan pencarian informasi yang dilakukan oleh konsumen, maka konsumen akan menemukan berbagai produk yang dapat memuaskan dan memecahkan permasalah yang dihadapi oleh konsumen. Dari berbagai produk tersebut, konsumen akan mengevaluasi atau memberikan nilai produk berdasarkan persepsi, motivasi dan lainnya yang memengaruhi keputusan pembelian konsumen. 


\section{FAKTOR-FAKTOR YANG MEMENGARUHI KEPUTUSAN PEMBELIAN HIJAB MEREK RABBANI PADA CV. RABBANI ASYSA CABANG PADANGSIDIMPUAN}

4) Tahap Keputusan Pembelian

Tahap evaluasi konsumen, akan memberikan nilai atas suatu produk berdasarkan merek (merek berfungsi sebagai identifikasi dan diferensiasi). Penilaian yang dilakukan konsumen akan mengundang niat konsumen untuk membeli atau justru menyebabkan konsumen tidak berkenan untuk mengkonsumsi produk tersebut. Ditahap inilah konsumen memutuskan untuk mengkonsumsi atau tidak suatu produk.

5) Tahap Perilaku Pasca Pembelian

Setelah melalui tahap-tahap tersebut, konsumen akan menggunakan produk pilihannya. Hal ini akan menghasilkan pengalaman bagi konsumen. Jika konsumen puas terhadap produk tersebut, kemungkinan ia akan melakukan pembelian ulang. Konsumen yang puas akan suatu produk akan menyatakan hal-hal yang baik mengenai produk tersebut. Dan secara tidak langsung akan menjadi sarana promosi yang baik bagi produk tersebut.

Contoh kasus untuk pengambilan keputusan model 5(lima) tahap dapat adalah ketika seorang mahasiswi hendak melakukan pembelian hijab karena kebutuhan akan hijab, maka mahasiswi tersebut akan melakukan pencarian informasi mengenai hijab yang dibutuhkannya, seperti mengamati desain, warna, bahan, harga dan merek yang tersedia untuk hijab. Jika telah menemukan informasi mengenai hijab yang dibutuhkannya, tahap selanjutnya mahasiswi tersebut akan menemukan berbagai hijab dengan berbagai warna, bentuk, harga dan merek. Maka mahasiswi tersebut akan melakukan evaluasi terhadap berbagai alternatif/pilihan hijab tersebut. Setelah melakukan evaluasi alternatif, maka peneliti tersebut akan memutuskan untuk membeli atau tidak. Jika mahasiswi tersebut melakukan pembelian, maka akan melakukan tahap pasca pembelian, setelah mengunakan hijab yang dipilih mahasiwi tersebut 
akan memberikan penilaian tersendiri mengenai hijab yang dibelinya tersebut. Hasil penilaian tersebut akan menjadi landasan keputusan bagi mahasiswi tersebut untuk melakukan pembelian ulang atau tidak.

Berdasarkan kedua model tahap pengambilan keputusan tersebut, maka dapat dinyatakan bahwa pengambilan keputusan pembelian secara sederhananya terbagi menjadi tiga, namun dapat dibagi kedalam beberapa tahap. Model-model pengambilan keputusan tersebut tidak selalu diaplikasikan oleh konsumen. Hal ini dikarenakan, konsumen terkadang lebih impulsif (mengikuti kehendak hati) tanpa terlalu mempertimbangkan berbagai faktorfaktor lain. Berdasarkan tingkat keterlibatan konsumen, proses keputusan pembelian konsumen akhir dapat dikelompokkan menjadi tiga macam, yaitu (Fandi Tjiptono, 2015):

1) Nominal (habitual) decision making, merupakan proses pembelian dikarenakan telah loyal dan memiliki ikatan emosional dengan merek spesifik yang dipandang telah memenuhi kebutuhan konsumen yang bersangkutan atau justru tidak memiliki ikatan akan tetapi tetap melakukan pembelian dikarenakan kebutuhan akan produk.

2) Limited decision making, merupakan proses pengambilan keputusan berdasarkan pengetahuan tanpa atau hanya sedikit usaha untuk mencari suatu informasi mengenai yang dibutuhkan. Hal ini biasanya dilakukan untuk pembelian yang berulang atau karena kebiasaan.

Extended decision making, merupakan proses pengambilan keputusan yang paling lengkap mulai dari identifikasi masalah hingga tahap pascapembelian. Proses pengambilan keputusan ini dipengaruhi oleh berbagai faktor baik faktor pemasaran maupun faktor-faktor lainnya. 


\section{FAKTOR-FAKTOR YANG MEMENGARUHI KEPUTUSAN \\ PEMBELIAN HIJAB MEREK RABBANI PADA CV. RABBANI ASYSA \\ CABANG PADANGSIDIMPUAN}

\section{Faktor-Faktor yang Memengaruhi Keputusan Pembelian}

Berdasarkan gambar model sederhana pengambilan keputusan maka dapat dipahami salah satu faktor yang memengaruhi keputusan konsumen adalah faktor sosiologis, faktor tersebut lebih jelasnya diuraikan sebagai berikut (Fandi Tjiptono, 2015):

1) Faktor Budaya

Faktor budaya dibagi menjadi kultur, subkultur dan kelas sosial. Faktor budaya merupakan faktor yang paling fundamental dalam memengaruhi keputusan pembelian. Keadaan budaya setempat akan sangat menentukan bagaimana seseorang bertindak. Untuk subbudaya dapat dimisalkan dengan negara konsumen, meskipun kewarganegaraan konsumen tidak begitu berpengaruh, namun pada realitasnya konsumen tidak dapat lepas dari pengaruh negara yang ditempatinya terhadap keputusan pembeliannya. Sedangkan untuk kelas sosial, konsumen dengan kelas sosial yang sama akan berperilaku yang lebih mirip dibandingkan dengan konsumen yang berbeda kelas sosial dengannya.

\section{2) Faktor Sosial}

Perilaku konsumen juga dipengaruhi oleh faktor sosial, seperti kelompok acuan, keluarga serta peran dan status konsumen. Baik secara langsung maupun tidak langsung seorang konsumen dipengaruhi oleh kelompok acuannya sendiri. Hal ini terjadi karena konsumen tersebut terinspirasi dari berbagai pihak. Di samping kelompok acuan keputusan konsumen juga sangat dipengaruhi oleh keluarga konsumen. Keluarga mempunyai aturan sendiri yang menciptakan pribadi konsumen. Dan berbagai keputusan konsumen akan sangat bergantung terhadap pengaruh keluarga konsumen. Status dan kedudukan konsumen akan memengaruhi peran konsumen tersebut. Status, kedudukan dan peran konsumen tersebut akan memberikan pengaruh terhadap keputusan konsumen. 


\section{3) Faktor Pribadi}

Faktor pribadi usia dan tahap siklus hidup, pekerjaan, keadaan ekonomi, gaya hidup akan memberikan pengaruh yang signifikan terhadap pengambilan keputusan konsumen. Usia seorang konsumen akan menentukan produk seperti apa yang dibutuhkannya. Diantara berbagai produk yang cocok dengan konsumen pekerjaan dan keadaan ekonomi konsumen akan menentukan produk seperti apa yang hendak dikonsumsi konsumen. Gaya hidup seseorang juga akan menentukan pola konsumsi dan barang seperti apa yang akan dikonsumsi konsumen.

\section{4) Faktor Psikologis}

Empat faktor utama psikologis yang memengaruhi keputusan konsumen, yaitu motivasi, persepsi, pengetahuan serta kepercayaan dan pendirian. Motivasi merupakan dorongan yang tercipta dari diri konsumen karena adanya kebutuhan. Selain motivasi, pengetahuan konsumen juga memengaruhi keputusan konsumen. Hal ini dikarenakan ada begitu banyaknya alternatif pilihan yang dimiliki oleh konsumen. Tingkat pengetahuan konsumenlah yang akan menyaring berbagai alternatif tersebut sehingga tercipta pilihan yang sesuai dengan konsumen. Disamping hal tersebut, konsumen akan mengonsumsi produk yang sesuai dengan gaya hidupnya yang akan menambah rasa percaya dirinya dan sesuai dengan pendiriannya.

\section{Hipotesis}

Hipotesis adalah suatu pendapat atau kesimpulan sementara, dan dalam arti sebenarnya masih memerlukan pengujian (Rosady Ruslan, 2012). Biasanya hipotesis menunjukkan hubugan antara 2 (dua) variabel atau lebih. Hipotesis juga dapat diartikan sebagai suatu penjelasan sementara tentang perilaku, fenomena atau keadaan tertentu yang telah terjadi atau akan terjadi. Pendapat atau penjelasan tersebut dilakukan secara ilmiah dan logis. Hipotesis yang 


\section{FAKTOR-FAKTOR YANG MEMENGARUHI KEPUTUSAN PEMBELIAN HIJAB MEREK RABBANI PADA CV. RABBANI ASYSA CABANG PADANGSIDIMPUAN}

disusun menjadi pedoman untuk mengarahkan penelitian agar diperoleh hal yang diinginkan. Peneliti harus menemukan data yang mendukung atau menolak hipotesis yang disusun (Mudrajat Kuncoro, 2003). Berdasarkan rumusannya, hipotesis dibagi menjadi dua:

1. Hipotesis nol $\left(\mathrm{H}_{0}\right)$ merupakan hipotesis yang menyatakan ketidakadanya hubungan antar variabel.

2. Hipotesis alternatif atau hipotesis kerja $\left(\mathrm{H}_{\mathrm{a}}\right)$ adalah hipotesis yang menyatakan adanya hubungan antar variabel (Suharsimi Arikunto, 2013).

Adapun hipotesis dalam penelitian ini adalah:

$\mathrm{H}_{01}=$ Tidak ada pengaruh yang signifikan antara faktor hargaterhadap keputusan pembelian hijab merek Rabbani pada CV.Rabbani Asysa Cabang Padangsidimpuan.

$\mathrm{H}_{\mathrm{a} 1}=$ Adapengaruh yang signifikan antara faktor hargaterhadap keputusan pembelian hijab merek Rabbani pada CV.Rabbani Asysa Cabang Padangsidimpuan.

$\mathrm{H}_{02}=$ Tidak ada pengaruh yang signifikan antara faktor kualitas terhadap keputusan pembelian hijab merek Rabbani pada CV.Rabbani Asysa Cabang Padangsidimpuan.

$\mathrm{H}_{\mathrm{a} 2}=$ Adapengaruh yang signifikan antara faktor kualitasterhadap keputusan pembelian hijab merek Rabbani pada CV.Rabbani Asysa Cabang Padangsidimpuan.

$\mathrm{H}_{03}=$ Tidak ada pengaruh yang signifikan antara faktor merek terhadap keputusan pembelian hijab merek Rabbani pada CV.Rabbani Asysa Cabang Padangsidimpuan. 
$\mathrm{H}_{\mathrm{a} 3}=$ Adapengaruh yang signifikan antara faktor merekterhadap keputusan pembelian hijab merek Rabbani pada CV. Rabbani Asysa Cabang Padangsidimpuan.

$\mathrm{H}_{04}=$ Tidak ada pengaruh yang signifikan antara faktor harga,kualitas, dan merek secara simultan terhadap keputusan pembelian hijab merek Rabbani pada CV.Rabbani Asysa Cabang Padangsidimpuan.

$\mathrm{H}_{\mathrm{a} 4} \quad=$ Ada pengaruh yang signifikan antara faktor harga,kualitas, dan merek secara simultan terhadap keputusan pembelian hijab merek Rabbani pada CV. Rabbani Asysa Cabang Padangsidimpuan.

\section{METODE PENELITIAN}

Analisis regresi berganda melibatkan banyak variabel bebas (lebih dari satu variabel bebas) (Agus Irianto, 2004). Regresi ganda (multiple regression) berguna untuk mencari pengaruh dua variabel prediktor atau mencari hubungan fungsional dua variabel prediktor atau lebih terhadap variabel kriteriumnya, atau untuk meramalkan dua variabel prediktor atau lebih terhadap variabel kriterium (Hartono, 2004).

Regresi ini merupakan satu teknik parametrik yang digunakan untuk menganalisis hubungan antara dua atau lebih variabel bebas dangan satu variabel tunggal. Untuk lebih jelas, maka berikut ini skema model regresi ganda (multiple regression).

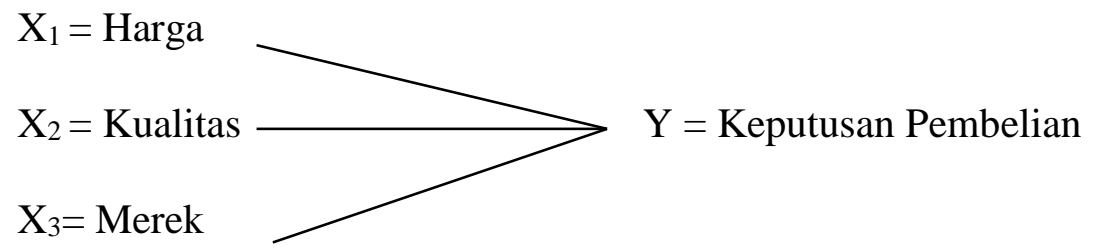

Dalam penelitian ini terdapat 3 (tiga) variabel bebas atau yang disimbolkan dengan $\mathrm{X}$, dan terdapat 1 (satu) variabel terikat (Y). Sehingga 


\section{FAKTOR-FAKTOR YANG MEMENGARUHI KEPUTUSAN PEMBELIAN HIJAB MEREK RABBANI PADA CV. RABBANI ASYSA CABANG PADANGSIDIMPUAN}

bentuk persamaan regresi ganda dengan menggunakan 3 (tiga) variabel bebas adalah sebagai berikut :

$Y=a+b_{1} X_{1}+b_{2} X_{2}+b_{3} X_{3}+e$

Keterangan :

$\mathrm{Y}=$ Nilai prediksi variabel terikat (Keputusan konsumen)

$\mathrm{a}=$ Konstanta, yaitu nilai $\mathrm{Y}$ jika $\mathrm{X}_{1}, \mathrm{X}_{2}, \mathrm{X}_{3}=0$

$\mathrm{b}=$ Koefisien regresi

$\mathrm{X}_{1}=$ Harga

$\mathrm{X}_{2}=$ Kualitas

$\mathrm{X}_{3}=$ Merek

$\mathrm{e}=$ Standard error term

\section{Pengujian Asumsi Klasik}

Uji asumsi klasik digunakan untuk menguji normalitas data penelitian, uji multokilinearitas, uji heteroskedastisitas dan uji autokorelasi. Menurut (Sugiono dan Susanto, 2015), uji normalitas bertujuan untuk menguji data penelitian baik variabel dependen maupun variabel independen terdistribusi normal atau tidak dengan menggunakan kolmogrov-smirnow pada taraf signifikan 0,1. Dan uji multikolinieritas digunakan untuk melihat adanya hubungan linier sempurna diantara variabel independennya dengan melihat nilai VIF (Variance Inflasion Factor). Dan uji heteroskedastisitas digunakan untuk mengetahui ada atau tidaknya penyimpangan asumsi klasik melalui penyebaran titik yang tidak membentuk pola. Dan mengukur uji autokorelasi dengan melihat hasil uji Durbin-Watson (DW).

\section{Pengujian Hipotesis}

Uji hipotesis digunakan untuk mengukur besarnya pengaruh variabel independen terhadap variabel dependen. Untuk mengukur seberapa jauh kemampuan model dalam menerangkan variasi dependen digunakan uji koefisien determinasi $\left(\mathrm{R}^{2}\right)$, menurut (Setiawan dan Kusrini, 2010), nilai yang mendekati satu berarti variabel-variabel independen memberikan hampir semua informasi yang dibutuhkan untuk memprediksi variasi variabel dependen. Untuk mengetahui apakah ada model regresi variabel independen secara parsial berpengaruh signifikan terhadap variabel dependen, maka digunakanlah uji $t$, menurut (Siregar, 2014), kaidah pengujian untuk menguji secara parsial yaitu jika $T_{\text {hitung }} \leq T_{\text {tabel }}$ maka 
$\mathrm{H}_{\mathrm{o}}$ diterima dan $\mathrm{H}_{\mathrm{a}}$ ditolak, dan jika $\mathrm{T}_{\text {hitung }} \geq \mathrm{T}_{\text {tabel }}$ maka $\mathrm{H}_{\mathrm{o}}$ ditolak dan $\mathrm{H}_{\mathrm{a}}$ diterima. Dan untuk mengetahui pengaruh semua variabel independen terhadap variabel dependen maka digunakanlah uji F, uji ini dilakukan dengan syarat bila $\mathrm{F}_{\text {hitung }}<\mathrm{F}_{\text {tabel }}$ maka $\mathrm{H}_{\mathrm{o}}$ diterima dan $\mathrm{H}_{\mathrm{a}}$ ditolak, bila $\mathrm{F}_{\text {hitung }}>\mathrm{F}_{\text {tabel }}$ maka $\mathrm{H}_{\mathrm{o}}$ ditolak dan $\mathrm{H}_{\mathrm{a}}$ diterima.

\section{HASIL DAN PEMBAHASAN}

Sebelum melakukan analisis data, terlebih dahulu menentukan uji normalitas dari data penelitian, adapun hasil uji normalitas penelitian ini adalah :

Tabel 1

Hasil Uji Normalitas

\begin{tabular}{|ll|r|}
\hline & & $\begin{array}{r}\text { Unstandardiz } \\
\text { ed Residual }\end{array}$ \\
\hline $\mathrm{N}$ & & 85 \\
Normal Parameters & Mean &, 0000000 \\
& Std. & 1,68648640 \\
& Deviation &, 086 \\
Most Extreme & Absolute &, 050 \\
Differences & Positive &,- 086 \\
& Negative &, 086 \\
Test Statistic & &, $169^{c}$ \\
\hline
\end{tabular}

Sumber: Hasil Penelitian (data diolah, 2018)

Berdasarkan hasil tersebut dapat dilihat nilai signifikasi yang diperoleh sebesar 0,169>0,05 maka $\mathrm{H}_{0}$ diterima sehingga kesimpulannya adalah sampel berasal dari populasi yang berdistribusi normal.

Tabel 2

Hasil Uji Multikolinearitas

\begin{tabular}{|c|c|c|}
\hline \multirow[b]{2}{*}{ Model } & \multicolumn{2}{|c|}{ Collinearity Statistics } \\
\hline & Tolerance & VIF \\
\hline 1 (Constant) & & \\
\hline Harga & 674 & 1,484 \\
\hline Kualitas & ,915 & 1,093 \\
\hline Merek & 671 & 1,491 \\
\hline
\end{tabular}




\section{FAKTOR-FAKTOR YANG MEMENGARUHI KEPUTUSAN PEMBELIAN HIJAB MEREK RABBANI PADA CV. RABBANI ASYSA CABANG PADANGSIDIMPUAN}

Berdasarkan tabel tersebut maka diperoleh nilai tolerance variabel harga $\left(\mathrm{X}_{1}\right)=0,674$ $>0,1$. Dan nilai tolerance variabel kualitas $\left(\mathrm{X}_{2}\right)=0,915>0,1$, sedangkan untuk variabel merek $\left(X_{3}\right)=0,671>0,1$. Sehingga berdasarkan nilai tolerance disimpulkan bahwa variabel harga $\left(\mathrm{X}_{1}\right)$, kualitas $\left(\mathrm{X}_{2}\right)$ dan merek $\left(\mathrm{X}_{3}\right)$ bebas dari multikolinearitas. Berdasarkan nilai VIF variabel harga $\left(X_{1}\right)=1,484<10$, nilai VIF variabel kualitas $\left(X_{2}\right)=1,093<10$ dan nilai variabel merek $=1,491<10$. Berdasarkan nilai VIF disimpulkan bahwa variabel harga $\left(\mathrm{X}_{1}\right)$, kualitas $\left(\mathrm{X}_{2}\right)$ dan merek $\left(\mathrm{X}_{3}\right)$ bebas dari multikolinearitas..

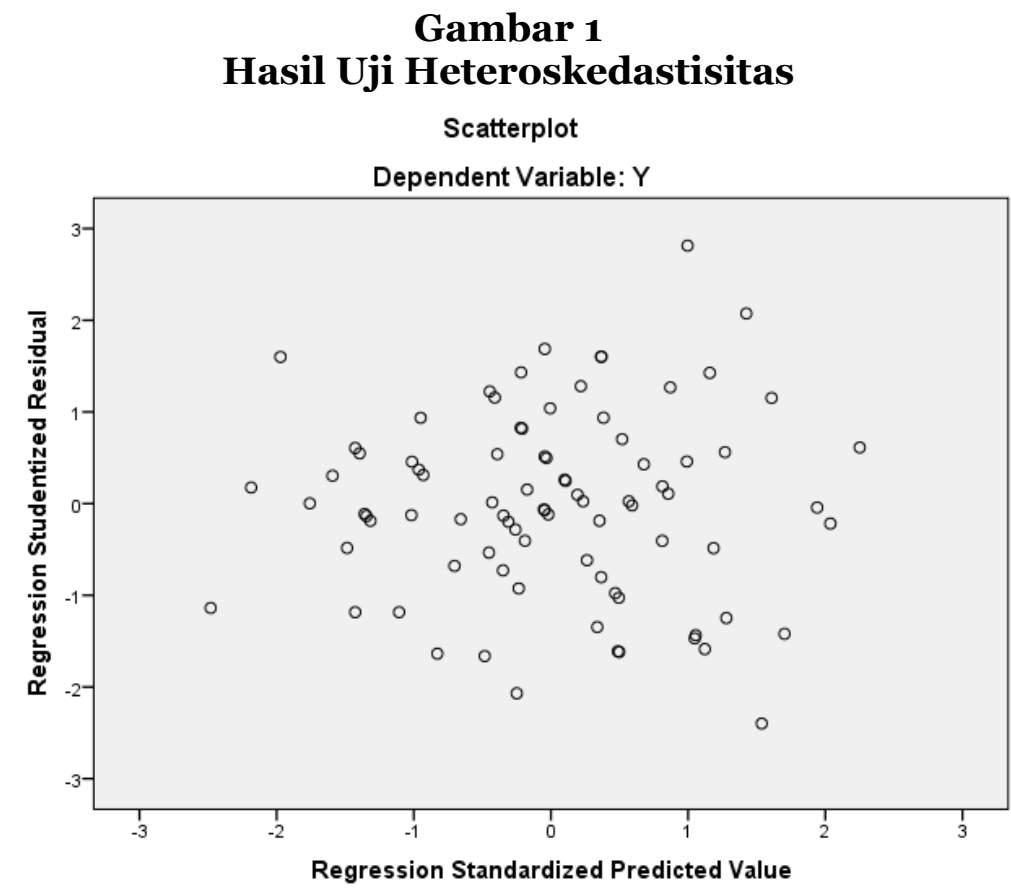

Berdasarkan gambar tersebut tidak ditemukan pola tertentu, seperti titiktitik yang ada membentuk suatu pola tertentu yang teratur (bergelombang, melebur kemudian menyempit), sehingga disimpulkan tidak terjadinya heterokedastisitas. 
Volume 6 Nomor 1 Ed. Januari-Juni 2018 : hal. 38-57

p-ISSN: 2356-4628 e-ISSN : 2579-8650

Tabel 3

Analisis Regresi Linier Berganda

\begin{tabular}{|c|c|c|c|c|c|}
\hline \multirow[b]{2}{*}{ Model } & \multicolumn{2}{|c|}{$\begin{array}{c}\text { Unstandardized } \\
\text { Coefficients }\end{array}$} & \multirow{2}{*}{$\begin{array}{c}\text { Standardized } \\
\text { Coefficients } \\
\text { Beta }\end{array}$} & & \multirow[b]{2}{*}{ Sig. } \\
\hline & $\mathrm{B}$ & Std. Error & & & \\
\hline $1 \quad$ (Constant) &,- 755 & 1,695 & &,- 446 & ,657 \\
\hline $\mathrm{X} 1$ & ,088 &, 040 &, 145 & 2,185 & ,032 \\
\hline $\mathrm{X} 2$ & 099, & ,038 & , 147 & 2,571 & ,012 \\
\hline $\mathrm{X} 3$ & ,454 & ,041 & ,729 & 10,953 & ,000 \\
\hline
\end{tabular}

Sumber: Hasil Penelitian (data diolah, 2018)

Berdasarkan tabel di atas dapat dilihat nilai unstandarlized coefficients bagian kolom B, maka persamaan analisis regresi linier berganda dalam penelitian ini adalah:

$$
Y=a+b_{1} X_{1}+b_{2} X_{2}+b_{3} X_{3}+e
$$

Keterangan :

$\mathrm{Y}=$ Nilai prediksi variabel terikat (Keputusan konsumen)

$\mathrm{a}=$ Konstanta, yaitu nilai $\mathrm{Y}$ jika $\mathrm{X}_{1}, \mathrm{X}_{2}, \mathrm{X}_{3}=0$

$\mathrm{b}=$ Koefisien regresi

$\mathrm{X}_{1}=$ Harga

$\mathrm{X}_{2}=$ Kualitas

$\mathrm{X}_{3}=$ Merek

$\mathrm{e}=$ Standard error term

Sehingga,

Keputusan Pembelian $=(-, 755)+0,088$ Harga + 0,099 Kualitas $+0,454$ Merek

Untuk mengetahui seberapa besar pengaruh variabel independen terhadap variabel dependennya, dapat dilihat pada tabel berikut : 


\section{FAKTOR-FAKTOR YANG MEMENGARUHI KEPUTUSAN \\ PEMBELIAN HIJAB MEREK RABBANI PADA CV. RABBANI ASYSA \\ CABANG PADANGSIDIMPUAN}

\section{Hasil Uji Determinasi $\mathbf{R}^{2}$}

\begin{tabular}{|l|c|r|r|r|}
\hline Model & R & R Square & \multicolumn{1}{|c|}{$\begin{array}{c}\text { Adjusted R } \\
\text { Square }\end{array}$} & $\begin{array}{c}\text { Std. Error of } \\
\text { the Estimate }\end{array}$ \\
\hline 1 &, $871^{\mathrm{a}}$ &, 759 &, 750 & 1,717 \\
\hline
\end{tabular}

Sumber: Hasil Penelitian (data diolah, 2018)

Berdasarkan tabel tersebut, diketahui bahwa nilai $\mathrm{R}^{2}$ (Adjusted $R$ Square) $=0,750$ mendekati 1. Hal ini menunjukkan bahwa $75 \%$ variabel harga, kualitas dan merek memengaruhi keputusan pembelian merek hijab Rabbani. Sedangkan 25\% (100 - 75) dipengaruhi oleh faktor lain yang tidak disebutkan dalam penelitian ini.

\section{Pembahasan Hasil Penelitian}

Penelitian ini berjudul Faktor-Faktor yang Memengaruhi Keputusan Pembelian Hijab Merek Rabbani pada CV. Rabbani Asysa Cabang Padangsidimpuan. Dari hasil analisis data yang dilakukan pada penelitian ini dengan menggunakan SPSS Versi 23 diketahui bahwa:

1. Hasil uji validitas untuk 39 item pertanyaan dari 3 (tiga) variabel bebas dan 1 (satu) variabel terikat diketahui memiliki $r_{h i t u n g}>r_{\text {tabel,. }}$ Dimana $r_{\text {tabel }}$ dengan taraf signifikasi $5 \%$ dengan derajat kebebasan $(\mathrm{df})=\mathrm{n}-2$, atau $\mathrm{df}=85-2=83$ adalah 0,2133, sedangkan nilai $\mathrm{r}_{\text {hitung }}$ dapat dilihat pada hasil Correted Item-Total Correlation. Karena $\boldsymbol{r}_{\text {hitung }}>\mathrm{r}_{\text {tabel }}$ dan bernilai positif maka 37 item pertanyaan dinyatakan valid dan 2 pertanyaan $\mathrm{r}_{\text {hitung }}<\mathrm{r}_{\text {tabel }}$ yaitu pertanyaan ke-5 pada variabel harga $\left(\mathrm{X}_{1}\right)$ dan pertanyaan ke-25 pada variabel merek $\left(\mathrm{X}_{3}\right)$ dinyatakan tidak valid. Selanjutnya, hasil uji reliabilitas diketahui bahwa dari ketiga variabel bebas (X) dan satu variabel terikat (Y) memiliki Cronbach's Alpha> 0,6 sehingga item pertanyaan pada kuesioner juga dapat dinyatakan reliabel. 
2. Hasil uji normalitas dengan SPSS Versi 23 berdasarkan uji Kolmogorov Smirnov. Nilai signifikasi yang diperoleh sebesar $0,169>0,05$ maka $\mathrm{H}_{0}$ diterima sehingga kesimpulannya adalah sampel berasal dari populasi yang berdistribusi normal.

3. Hasil uji liniearitas untuk variabel bebas $(\mathrm{X})$ terdiri dari tiga variabel yaitu harga $\left(\mathrm{X}_{1}\right)$, kualitas $\left(\mathrm{X}_{2}\right)$ dan merek $\left(\mathrm{X}_{3}\right)$ dengan variabel terikat yaitu keputusan pembelian $(\mathrm{Y})$, menunjukkan terjadi regresi yang linier dengan nilai $\mathrm{F}_{\text {hitung }}>$ nilai $\mathrm{F}_{\text {tabel }}$ maka $\mathrm{H}_{0}$ diterima kesimpulannya terjadi regresi linier.

4. Hasil uji multikolinearitas menunjukkan penelitian ini bebas dari multikolinearitas, hal ini dapat dilihat berdasarkan nilai tolerance yangmenunjukkan bahwa variabel bebas yaitu harga $\left(\mathrm{X}_{1}\right)$, kualitas $\left(\mathrm{X}_{2}\right)$ merek $\left(\mathrm{X}_{3}\right)>0$,1. Dan berdasarkan nilai VIF variabel harga $\left(\mathrm{X}_{1}\right)$ kualitas $\left(\mathrm{X}_{2}\right)$ dan merek $\left(\mathrm{X}_{3}\right)<10$.

5. Hasil uji heterokedatisitas menunjukkan bahwa tidak ditemukan pola tertentu, seperti titik-titik yang ada membentuk suatu pola tertentu yang teratur (bergelombang, melebur kemudian menyempit), sehingga disimpulkan tidak terjadinya heterokedastisitas.

6. Persamaan analisis regresi linier berganda dalam penelitian ini adalah:

$Y=a+b_{1} X_{1}+b_{2} X_{2}+b_{3} X_{3}+e$

Sehingga,

Keputusan Pembelian $=(-, 755)+0,088$ Harga + 0,099 Kualitas $+0,454$ Merek

7. Hasil nilai $\mathrm{R}^{2}$ (Adjusted $R$ Square) $=0,750$ mendekati 1 . Hal ini menunjukkan bahwa $75 \%$ variabel harga, kualitas dan merek memengaruhi keputusan pembelian merek hijab Rabbani. Sedangkan 25\% (100 - 75) dipengaruhi oleh faktor lain yang tidak disebutkan dalam penelitian ini.

8. Hasil uji t menunjukkan bahwa nilai thitung variabel bebas (harga $\left(\mathrm{X}_{1}\right)$, kualitas $\left(\mathrm{X}_{2}\right)$ dan merek $\left.\left(\mathrm{X}_{3}\right)\right)>\mathrm{t}_{\text {tabel }} 1,989$ maka $\mathrm{H}_{0}$ ditolak dan $\mathrm{H}_{\mathrm{a}}$ diterima, sehingga 


\section{FAKTOR-FAKTOR YANG MEMENGARUHI KEPUTUSAN \\ PEMBELIAN HIJAB MEREK RABBANI PADA CV. RABBANI ASYSA \\ CABANG PADANGSIDIMPUAN}

kesimpulannya secara parsial terdapat pengaruh yang signifikan antara variabel bebas (harga $\left(\mathrm{X}_{1}\right)$, kualitas $\left(\mathrm{X}_{2}\right)$ dan merek $\left(\mathrm{X}_{3}\right)$ ) terhadap keputusan pembelian hijab merek Rabbani .

9. Hasil uji nilai $\mathrm{F}$ menujukkan bahwa nilai $\mathrm{F}_{\text {hitung }}$ yang diperoleh adalah 85,141 > $\mathrm{F}_{\text {tabel }}=2,72$, maka variabel bebas yaitu harga, kualitas dan merek secara bersamasama (simultan) berpengaruh terhadap variabel terikat yaitu keputusan pembelian.

\section{KESIMPULAN}

Berdasarkan hasil penelitian dan pembahasan maka kesimpulan yang diperoleh peneliti dalam penelitian ini adalah sebagai berikut:

1. Hasil uji secara parsial (uji t) variabel harga (X1) menunjukkan bahwa nilai thitung harga $\left(\mathrm{X}_{1}\right)=2,185>\mathrm{t}_{\text {tabel }} 1,989$ maka $\mathrm{H}_{0}$ ditolak dan $\mathrm{H}_{\mathrm{a}}$ diterima, sehingga kesimpulannya terdapat pengaruh yang signifikan antara harga terhadap keputusan pembelian hijab merek Rabbani.

2. Hasil uji secara parsial (uji t) variabel kualitas $\left(\mathrm{X}_{2}\right)$ menunjukkan bahwa nilai thitung kualitas $\left(\mathrm{X}_{2}\right)=2,571>\mathrm{t}_{\text {tabel }} 1,989$ maka $\mathrm{H}_{0}$ ditolak dan $\mathrm{H}_{\mathrm{a}}$ diterima, sehingga kesimpulannya terdapat pengaruh yang signifikan antara kualitas terhadap keputusan pembelian hijab merek Rabbani.

3. Hasil uji secara parsial (uji t) variabel merek $\left(\mathrm{X}_{2}\right)$ menunjukkan bahwa nilai $\mathrm{t}_{\text {hitung }}$ merek $\left(\mathrm{X}_{2}\right)=10,953>\mathrm{t}_{\text {tabel }} 1,989$ maka $\mathrm{H}_{0}$ ditolak dan $\mathrm{H}_{\mathrm{a}}$ diterima, sehingga kesimpulannya terdapat pengaruh yang signifikan antara merek terhadap keputusan pembelian hijab merek Rabbani.

4. Hasil uji secara simultan (uji F) adalah nilai $F_{\text {hitung }}$ yang diperoleh adalah Hasil uji nilai $\mathrm{F}$ menujukkan bahwa nilai $\mathrm{F}_{\text {hitung }}$ yang diperoleh adalah 85,141 $>\mathrm{F}_{\text {tabel }}=2,72$, 
maka variabel bebas yaitu harga, kualitas dan merek secara bersama-sama (simultan) berpengaruh terhadap variabel terikat yaitu keputusan pembelian.

5. Persamaan analisis regresi linier berganda dalam penelitian ini adalah:

$Y=a+b_{1} X_{1}+b_{2} X_{2}+b_{3} X_{3}$

Sehingga,

Keputusan Pembelian $=(-, 755)+0,088$ Harga + 0,099 Kualitas + 0,454 Merek

Berdasarkan persamaan tersebut dapat dijelaskan bahwa keputusan pembelian adalah sebesar $(-, 755)$ apabila harga, kualitas dan merek dianggap konstan 0. Apabila nilai harga meningkat 1 satuan maka keputusan pembelian hijab merek Rabbani meningkat sebesar 0,088 satuan. Apabila nilai kualitas meningkat 1 satuan maka keputusan pembelian hijab Rabbani meningkat 0,099 dan apabila nilai merek meningkat 1 satuan maka keputusan pembelian hijab merek Rabbani meningkat 0,454 satuan. Hasil uji keofisien determinasi $\left(\mathrm{R}^{2}\right)$ bahwa $75 \%$ variabel harga, kualitas dan merek memengaruhi keputusan pembelian merek hijab Rabbani. Sedangkan 25\% (100 - 75) dipengaruhi oleh faktor lain yang tidak disebutkan dalam penelitian ini 


\section{FAKTOR-FAKTOR YANG MEMENGARUHI KEPUTUSAN \\ PEMBELIAN HIJAB MEREK RABBANI PADA CV. RABBANI ASYSA CABANG PADANGSIDIMPUAN}

\section{DAFTAR PUSTAKA}

Agus Irianto, Statistik: Konsep Dasar dan Aplikasinya, Jakarta: Kencana, 2004.

Departemen Agama, Al-Qur'an dan Terjemahannya, Bogor: PT. Sygma Examedia Arkanleema, 2007.

Fandi Tjiptono, Strategi Pemasaran Edisi 4, Yogyakarta: CV. Andi Offset, 2015.

Hartono, Statistik: Untuk Penelitian, Jakarta: $\mathrm{LSFK}_{2} \mathrm{P}, 2004$.

Leon Sciffman dan Leslie Lazar Kanuk, Perilaku Konsumen Edisi Ke-7,

diterjemahkan dari “Consumer Behaviour” oleh Zoelkifli Kasip, Jakarta:

Indeks, 2007.

Mudrajat Kuncoro, Metode Riset Untuk Bisnis Dan Ekonomi : Bagaimana Meneliti

Dan Menulis Tesis, Jakarta: Erlangga, 2003.

Philip Kotler dan Kevin Lane Keller, Manajemen Pemasaran diterjemahkan dari

“Marketing Management” oleh Bob Sabran, Jakarta: Erlangga, 2008.

Rosady Ruslan, Dasar-Dasar Manajemen Bank Syariah, Bandung: Alfabeta, 2012.

Setiawan dan Kusrini, Endah, Dwi. 2010. Ekonometrika, Yogyakarta : Andi.

Suharsimi Arikunto, Prosedur Penelitian suatu pendekatan praktek, Jakarta:

PT.Rineka Cipta, 2002.

Sugiono dan Susanto, Agus. 2015. Cara Mudah Belajar SPSS dan Lisrel Teori Dan Aplikasi Untuk Analisis Data Penelitian, Bandung : Alfabeta. 